\title{
PENERAPAN AKAD AS SALAM DALAM JUAL BELI BATU BATA MENURUT PERSPEKTIF EKONOMI ISLAM \\ ( Studi Kasus Desa Paloh Gadeng Kecamatan Dewantara Kabupaten Aceh Utara) \\ ${ }^{1}$ Munardi \\ ${ }^{2}$ Fuadi \\ ${ }^{3}$ Sri Nazarni \\ ${ }^{1}$ Islamic Economics Department, Faculty of Economics and Business, University of Malikussaleh \\ ${ }^{2}$ Islamic Economics Department, Faculty of Economics and Business, University of Malikussaleh \\ ${ }^{3}$ Islamic Economics Department, Faculty of Economics and Business, University of Malikussaleh \\ 1munardi@unimal.ac.id \\ 2fuadi.msm.@unimal.ac.id \\ 3sri.160440111@mhs.unimal.ac.id
}

\section{ARTICLE HISTORY}

Received:

25 April 2021

Revised

1 May 2021

Accepted:

27 May 2021

Online available:

19 Juni 2021

Keywords :

As-Salam contract, Islamic

Economic Perspective.

*Correspondence:

Name:

Sri Nazarni

E-mail:

sri.160440111@mhs.unimal.ac.id

\section{ABSTRACT}

This study aimed to determine the application of the contract Assalam to buying and selling bricks and knowing the Islamic economic review of the buying and selling of bricks. The method used was a descriptive qualitative method using data collection techniques through observation, interviews, and documentation. The data in this study came from several groups of people in Paloh Gadeng, Dewantara subdistrict, North Aceh Regency, namely: sellers and buyers, brick laborers, community leaders. The findings showed that most of the brick sellers in Paloh Gadeng Village had implemented the As-salam contract to facilitate transactions between the seller and the buyer in selling bricks by paying for the goods ordered in advance at the beginning of the transaction, and then the seller produced the order from the buyer. However, some sellers had not implemented the As-salam contract and made payments in full at the beginning of the transaction and immediately took orders for goods without waiting for the production process. 


\section{PENDAHULUAN}

Ajaran islam memerintahkan umatnya untuk memahami nilai-nilai agama islam secara menyeluruh atau kaffah, ajaran islam juga berkaitan dengan kewajiban yang individu untuk menyembah Allah SWT dan berkaitan dengan lingkungan dan sesama masyarakat. Pada dasarnya islam tidak melarang bagi umatnya untuk mencari karunia Allah yang tersebar di muka bumi. Meskipun adanya kebolehan dalam jual beli dalam islam, namun hal tersebut tidak dapat membantu memenuhi semua kebutuhan manusia. dengan berkembangnya teknologi yang mempengaruhi terhadap kebutuhan manusia, sehingga ada kebutuhan yang membutuhkan jarak dan waktu memperolehnya, hal ini akan mengurus waktu dan materi. perlu di ketahui bahwa tidak semua transaksi jual beli dilakukan secara kontan dikarenakan keterbatasan kemampuan dan juga barang yang di perdagangkan terkadang bukan barang yang mudah terjual. oleh karena itu untuk mengatasi hal tersebut muncul adanya jual beli pesanan. Bentuk kegiatan manusia yang lainnya dalam bermuamalah yaitu akad as salam ( jual beli dengan pembayaran di muka) adalah penjualan suatu barang yang masih berada dalam tanggungan pihak penjual, namun pembayaran terhadap barang tersebut dilakukan oleh pihak pembeli terlebih dahulu atau jual beli dengan pembayaran di muka, sedangkan barang dengan kriteria tertentu di serahkan pada waktu tertentu. Tingginya tingkat permintaan pembeli terhadap produksi batu bata menyebabkan proses transaksi jual beli batu bata dialihkan dengan pemesanan, dimana seorang pembeli bertemu langsung dengan pengrajin batu bata untuk membicarakan mengenai pemesanan batu bata yang dalam islam disebut dengan akad salam. Mengenai harga jualnya sendiri, antara pihak pembei dan penjual telah melakukan kesepakatan awal akad dengan pemberian uang muka.Namun, permasalahan yang terjadi dalam akad ini adalah ketika barang yang dipesan tersebut tidak sesuai dengan spesifikasi yang telah disepakati serta dalam penyelesaian dari masalah tersebut adanya penyimpangan-penyimpangan yang tidak sesuai dengan perspektif ekonomi islam sehingga timbullah konflik antara pembeli dan penjual.

\section{PENELITIAN TERDAHUU}

Eliza ( 2011 ) “Pelaksanaan Jual Beli Batu Bata Di Desa Ganting Kecamatan Salo Kabupaten Kampar Ditinjau Menurut Perspektif Islam" Metode yang digunakan dalam penelitian ini adalah pengumpulan data, observasi, wawancara dan dokumentasi. Tujuan penelitian untuk mengetahui bagaimana cara pelaksanaan jual beli batu bata dan tinjauan hukum ekonomi islam terhadap pelaksanaan jual beli batu bata Didesa Ganting Kecamatan Salo Kabupaten Kampar. Hasil penelitian ini bahwa pelaksanaan perdagaan secara pesanan yang dilakukan oleh para pedagang batu bata doi desa ganting dengan para distributor sebelum terjadinya pengiriman adalah dengan menyebutkan spesifikasi barang yang dipesan dari jenisnya, mutunya, beratnya, tempat dan waktu penyerahannya, sedangkan perjanjian hanya dengan lisan saja tanpa dituliskan dalam sebuah nota ataupun surat perjanjian.jika terjadi ketidaksesuaian barang pesanan dengan spesifikasi yang telah disepakati. Kemudian dikirim balik oleh pedagang kepada distributor, maka biaya pengiriman balik tersebut ditanggung oleh pedagang. 


\section{DESAIN PENELITIAN}

Penelitian ini menggunakan metode kualitataif dengan tipe penelitian deskriptif analisis. Pendekatan kualitatif bertujuan untuk mengungkapkan dan memahami sesuatu dibalik fenomena yang belum diketahui dan juga dapat memberikan rincian yang kompleks tentang fenomena yang sulit diungkapkan (Sugiyono, 2015). Metode pengambilan sampel yang digunakan dalam penelitian ini adalah non probability sampling, dimana elemen dari populasi tidak memiliki kesempatan yang sama untuk dipilih sebagai subjek penelitian.

\section{METODELOGI PENELITIAN}

Analisis data dilakukan selama penelitian, hal ini dimaksudkan agar fokus penelitian tetap diberi perhatian khusus melalui observasi dan wawancara mendalam, yang selanjutnya akan dianalisis secara kualitatif. Menurut Bogdan dan Bikler (1982) dalam penelitian (Rijali, 2018) analisis data kualitatif adalah upaya yang dilakukan dengan jalan bekerja dengan data, mengorganisasikan data, memilih-milihnya menjadi satuan yang dapat dikelola, mensistensiskannya, mencari dan menemukan pola, menemukan apa yang penting dan yang dipelajari, dan memutuskan apa yang dapat diceritakan kepada orang lain. Adapun tahap penelitian ini yaitu pengumpulan data, reduksi data, penyajian data, dan penerikan kesimpulan.

\section{HASIL DAN PEMBAHSAN}

Adapun hasil penelitian wawancara yang dilakukan peneliti kepada para pengrajin batu bata di desa Paloh Gadeng ini sebanyak 3 orang pengrajin dengan 7 buah pertayaan sebagai berikut:

- Bapak Muhammad "mengatakan memproduki batubata adalah untuk kebutuhan hidup dan juga pendidikan anaknya. Dari pertayaan pertama beliau mengatakan bahwa penerapan akad as-salam yaitu dengan melakukan pembayaran dimuka, pertayaan yang kedua jika ada pesanan batu bata maka pembeli datang lansung ke tempatnya, pertayaan ketiga apabila melakukan transaksi beliau melakukannya secara lisan dan juga tulisan, pertayaan keempat apabila terjadi kerusakan maka akan ditanggung oleh penjual namun harus ada kesepakatan terlebih dahulu, pertayaan kelima lama produksi batu bata tergantung dari jumlah pesanan apabila sedikit maka akan cepat siap dan begitu pula sebaliknya, pertayaan keenam harga dari stu pices batu bata ini yaitu seharga 220.00 per pices, pertayaan ketujuh upah yang diberikankepada para buruh sebesar 50.00 perpices batu batanya".

- Bapak Azhari “mengatakan memproduki batubata adalah untuk kebutuhan hidup dan juga pendidikan anaknya. Dari pertayaan pertama beliau mengatakan bahwa penerapan akad as-salam yaitu dengan melakukan pembayaran dimuka, pertayaan yang kedua jika ada pesanan batu bata maka pembeli datang lansung ke tempat dan juga melalui telepon seluler, pertayaan ketiga apabila melakukan transaksi beliau melakukannya secar tulisan seperti bon ataupun kwitansi, pertayaan keempat apabila terjadi kerusakan maka akan ditanggung oleh penjual namun harus ada kesepakatan terlebih dahulu, pertayaan kelima 
lama produksi batu bata tergantung dari jumlah pesanan apabila sedikit maka akan cepat siap dan begitu pula sebaliknya, pertayaan keenam harga dari stu pices batu bata ini yaitu seharga 220.00 per pices, pertayaan ketujuh upah yang diberikankepada para buruh sebesar 50.00 perpices batu batanya".

- Bapak Zulkifli “mengatakan memproduki batubata adalah untuk kebutuhan hidup dan juga pendidikan anaknya . Dari pertayaan pertama beliau mengatakan bahwa penerapan akad as-salam yaitu dengan melakukan pembayaran dimuka, pertayaan yang kedua jika ada pesanan batu bata maka pembeli datang lansung ke tempatnya, pertayaan ketiga apabila melakukan transaksi beliau melakukannya secara tulisan yaitu berupa bon atupun kwitansi agar tidak ada penipuan, pertayaan keempat apabila terjadi kerusakan maka akan ditanggung oleh penjual namun harus ada kesepakatan terlebih dahulu, pertayaan kelima lama produksi batu bata tergantung dari jumlah pesanan dan juga dari umlah karyawannya karena beliau hanya memiliki satu pengawai saja, pertayaan keenam harga dari stu pices batu bata ini yaitu seharga 220.00 per pices, pertayaan ketujuh upah yang diberikank epada para buruh sebesar 50.00 perpices batu batanya".

\section{KESIMPULAN}

Jual beli salam merupakan transaksi jual beli " pesanan " atau " indent " yang pembayarannya dilakukan ketika akad berlangsung dengan penyerahan barang di laksanakan di akhir sesuai dengan perjanjian yang telah di sepakati antara penjual dan pembeli. Praktek jual beli as salam merupakan jual beli tidak tunai di bolehkan dalam syariat islam sampai memenuhi persyaratan yang telah di tentukan yaitu ukuran, timbangan dan waktu yang telah disepakati. jual beli as salam juga tidak menyalahi qiyas dengan jual beli yang membolehkan penangguhan penyerahan barang seperti halnya di bolehkannya penanggulahan dalam pembayaran. Sebagian besar penjual batu bata di Desa Paloh Gadeng sudah menerapkan akad as salam agar mempermudah transaksi antara penjual dan pembeli dalam menjual batu bata, penerapan akad as salam dilakukan dengan cara membayar pesanan barang dimuka pada awal transaksi, lalu penjual baru memproduksi pesanan dari pembeli. Namun ada juga penjual yang belum menerapkan akad As-salam, Transaksi yang tidak menerapkan akad as salam melakukan pembayaran secara lunas pada awal transaksi dan langsung mengambil pesanan barang tanpa perlu menunggu proses produksi.Tinjauan ekonomi islam pada penerapan akad as salam di Desa Paloh Gadeng diperbolehkan untuk memudahkan transaksi antara penjual dan pembeli dalam pemesanan barang, Namun harus dilakukan sesuai dengan ketetapan syariat islam tidak boleh adanya kedzaliman dalam transaksi seperti kurangnya pesanan barang atau tidak sesuainya kualitas barang yang di terima oleh pembeli. 


\section{REFERENSI}

Abdul Aziz, D. (1996) Ensiklopedia Hukum Islam. Jakarta: Ichtiar baru Van hoeve.

Acarya (2009) Akad dan Produk Bank Syariah. Jakarta: PT. Raja Grafindo Persada.

Antonio, M. S. (2002) Bank Syariah Dari Teori Kepraktek. Jakarta: PT.Raja Grafindo.

Asqalani, I. al hajar Al (2001) Bulugh Al-Maram. Bandung: CV Diponogoro.

Basyir, A. azhar (2000) Asas-Asas Hukum Muamalat, Hukum Perdata Islam. UII Press. Yogyakarta.

ELIZA (2011) 'Pelaksanaan Jual Beli Batu Bata di Desa Ganting Kecamatan Salo Kabupaten Kampar Ditinjau Menurut Presfektif Ekonomi Islam', 3, p. 86.

Fadhli, A. (2016) 'Tinjauan Hukum Islam Terhadap Penerapan Akad As-salam Dalam Transaksi ECommerce', XV(1), pp. 1-19.

Hasan, M. A. (2004) Berbagai Macam Transaksi Dalam Islam. Jakarta: PT.Raja Grafindo.

Lubis, S. K. (2000) Hukum Ekonomi Islam. Jakarta: Sinar Grafika. 